\title{
Thought on the Construction of Enterprise Craftsmanship Culture Based on the Perspective of Enterprise Culture
}

\author{
Bai Lin \\ Shandong Huayu University of Technology, Dezhou, Shandong, China, 253034 \\ Keywords: Enterprise Culture; Craftsmanship Spirit; Cultivation of Craftsmanship Culture \\ Abstract: The paper herein may mainly discuss about the connotation of the construction of \\ enterprise craftsmanship culture based on the perspective of the building of enterprise culture. \\ It may propose the idea and method of the construction of craftsmanship spirit and culture.
}

\section{Introduction}

President Xi Jinping has pointed out that prosperity of a country or a nation may always base on the prosperity of culture. Without inheritance and development of civilization and enrichment and prosperity of culture can the Chinese dream come true. The manufacturing industry of a country, especially for the intelligent manufacturing, can't possess its real international competence and form into one world-famous brand without or lacking of craftsmanship culture. Craftsmanship culture is the one that is closely related to people's daily life and life of production and consumption.

As the economic entity of commodity, one enterprise that has great corporate culture formed during the process of management and development may definitely boast its core competence, which demonstrates that great corporate culture may be the spiritual pillar and source of power of the continuous development of one enterprise. The connotation system of enterprise culture contains three levels as material culture, spiritual culture and system culture. The paper herein will discuss about connotation and cultivation of enterprise craftsmanship culture.

\section{Connotation of Enterprise Craftsmanship Cullture}

\subsection{Theory of Enterprise Culture}

Enterprise culture, or also called organizational culture, is the peculiar culture image constituted of value, belief, rite, symbol and manner. Enterprise culture is the spiritual wealth and physical form with the unique feature of one enterprise formed in specified conditions during the production and management activities. Enterprise culture contains three levels presented as follow:

Firstly, the superficial level of material culture will be called the 'hard culture' of enterprise which contains several aspects as the face and feature of factory, mechanical equipment and sculpt, appearance and quality of product.

Secondly, the middle level is the system culture which contains leadership structure, interpersonal relationship and rules and regulations.

Thirdly, the core level is the spiritual culture, also called 'soft culture' of enterprise that contains 
code of conduct, sense of value, group consciousness of enterprise, staff quality and great traditions. It's the key part of enterprise culture.

\subsection{Connotation and Construction of Enterprise Craftsmanship Culture}

Enterprise craftsmanship culture, as the sub-culture of corporate culture, comes into being just as the structure of enterprise culture. The paper herein believes that enterprise craftsmanship culture consists of craftsmanship spirit, system and material. Enterprise craftsmanship culture belongs to the core part of enterprise culture. Craftsmanship spirit can be understood from several aspects. If we see from the part of supply, it mainly refers to the spirit of the pursuit of perfection and detail during the process of production; Craftsmanship system culture comes into being during the longtime operation of economic and social system. For enterprises, it refers to the collection of system made by enterprises for encouraging staff and mechanics to achieve the goal of production, which contains production system, check-up system, system of rewards and penalties and apprentice system. The culture of generating martial of craftsmanship, or also called entity culture, contains culture of implement and tool culture. In terms of generating material of craftsman, implement and tool are main parts to record the content of craftsmanship culture, which shows the civilization of implement and tool culture. With the time goes on, the traditional culture of implement and tool has continuously been used and created, which shows people throw away or eliminate some kinds of non-ideal implement or tool. Therefore, the implement and tool which are inherited and developed are all the great cultures in craftsmanship culture and become the material wealth of human. These implement and tool constitute the material wealth of the whole world and dominant living body of craftsmanship culture.

\section{Cultivation of Enterprise Craftsmanship Culture}

\subsection{Macro-environment-from the Perspective of Society}

The material culture should be constructed to support craftsmanship spirit. The material products and what the culture they show should meet the needs of people's living and development. The nature of material culture is competition. The key part of craftsmanship spirit that should be cultivated to show the spirit of perfection and the customer-oriented idea in the future lies in the enrichment of the soil of market competition and the acceleration of the improvement of marketing orientation in order to break the market monopoly.

\subsection{The behavior culture should be constructed to support craftsmanship spirit}

The behavior of consumers, especially for some picky behavior should be encouraged. American managerialist Baud once pointed out when researching the reason of refinement of commodity made in Japan it's the nearly harsh behavior of Japanese women when they are shopping that is the most important external pressure and impetus. However, the casual consuming behavior may connive at the nonfeasance of the construction of craftsmanship spirit of enterprises.

\subsection{Management culture should be constructed to support craftsmanship spirit}

In the aspect of management, the relationship between flexibility and observation of discipline should be well balanced. People of our nation may lack of craftsmanship spirit but most of time, craftsmanship spirit looks like sticking to certain steps while it is the wisdom of the other kind. People of our nation still have more to learn and make up the miss in this aspect. 


\subsection{System culture should be constructed to support craftsmanship spirit}

The establishment of craftsmanship spirit and craftsmanship system may be contributed to the way that government regulates the market. In order to create the soil for the enterprises who have the spirit of craftsmanship and encourage technological innovation and the improvement of product quality, government should strictly supervise market competitors and punish the illegal conduct of counterfeit and infringing upon intellectual property.

\subsection{Micro-environment-from the Perspective of Enterprises}

The construction of craftsmanship culture should be brought into enterprise strategic culture system. If an enterprise wants to realize sustainable development, then it has to have a longtime development goal and development planning. And moreover, the development direction of enterprise and how the development conducts should also be informed to all the staff as soon as possible. Only with the recognition of all the staff can the development strategy play an important role of guidance and become the action guideline of the whole staff. In the construction of enterprise culture, we should make full use of carriers like the Internet and take various methods to make development strategy of enterprise and promote enterprise craftsmanship culture. Moreover, we should step further to make clear thoughts of work, clearly define the development direction of enterprise and encourage the working enthusiasm of the whole staff.

\subsection{People-oriented culture of enterprise should be constructed}

Talents are the precious sources of the development of enterprise. In the new situation, enterprises need a large number of talents of different kinds and specialties. Enterprises should take the construction of the team of talents as the important part into consideration of the establishment enterprise craftsmanship culture. Enterprise should construct the cultural atmosphere of respecting talents, shaping talents and laying great emphasis on good craftsmen in order to strengthen the sense of belonging of staff and encourage the initiative and creation of staff.

\subsection{Enterprise system culture should be normalized}

The relationship between craftsmanship culture and enterprise system are mutually supportive and assistant and craftsmanship culture is the major constituent part of enterprise culture. In the construction of craftsmanship system culture, we should pay more attention to creation and cogent execution, which will help improve the degree of participation of democratic management and arouse the enthusiasm of the whole staff.

Craftsmanship culture with the core of craftsmanship spirit should be constructed. The craftsmanship spirit which lays great emphasis on perfection and the concept of consumer-oriented is the most important and detailed goal, belief, ethic and value of a powerful enterprise. Enterprises should interpret and carry out the craftsmanship spirit of their own in all-round direction based on the features of their industries.

\section{Conclusion}

In a word, the construction of enterprise craftsmanship culture is a complicated task. It should be considered from various perspectives from social environment to the construction of enterprise culture. Moreover, there also exist many realistic problems and difficulties, which means the construction may need the longtime cultivation and continuous establishment. From the macro- 
perspective we should lay more emphasis on the establishment of system culture and the culture of sense of value to build the sound social atmosphere while from the perspective of the construction of enterprises, the core part should be the integration of craftsmanship culture into strategic system. Secondly, we should pay attention to the construction of craftsmanship spirit culture, which can help shape the cultural environment of people-oriented and the craftsmanship cultural environment of generating material based on craftsmanship system culture. Only with the great effect of both society and enterprise can enterprise craftsmanship culture have sound and health development.

\section{Acknowledgement}

Project of fund: Subject of Education Department of Shandong Province Research on Construction and Cultivation of Craftsmanship Culture of Modern Manufacturing Enterprises under the Background of Made in China 2025 Strategy ( NO.J17RB097).

\section{References}

[1] Xu Jian. Craftsman spirit: the ultimate blooming of professional accomplishment [J]. Jiangsu Education: 2015, (44): 38-39.

[2] Li Xiaolu. Critique and reading of artisansundefinedspiritual vulgarization and superficial understanding [J]. Contemporary vocational education: 2016, (5): 4-6.

[3] Wang Liyuan. Study on the necessity and Feasibility of cultivating Student craftsman Spirit in higher Vocational Education [J]. Vocational Education Forum: 2014, (22): 66-69.

[4] Liu Xiao. On the Spirit of craftsmen and Vocational Education [J]. Jiangsu Education, 2015, (14): $20-22$.

[5] Meng Qingwei. The financial budget of vocational education is significantly lower than that of partial higher vocational accounts [N] China Business News 2016-08-22 (10).

[6] Xiao Qunzhong, Liu Yongchun. Artisansundefined Spirit and Contemporary value [J] Hunan Social Sciences, 2015, (6): 6-10. 